\title{
Divine empowerment: The Holy Spirit and church revitalisation
}

\begin{tabular}{|c|c|}
\hline \multicolumn{2}{|c|}{$\begin{array}{l}\text { Author: } \\
\text { Brian A. DeVries }{ }^{1,2,3}\end{array}$} \\
\hline \multicolumn{2}{|c|}{$\begin{array}{l}\text { Affiliations: } \\
{ }^{1} \text { Faculty of Theology, } \\
\text { North-West University, } \\
\text { Potchefstroom Campus, } \\
\text { South Africa }\end{array}$} \\
\hline \multicolumn{2}{|c|}{$\begin{array}{l}{ }^{2} \text { Mukhanyo Theological } \\
\text { College, KwaMhlanga, South } \\
\text { Africa }\end{array}$} \\
\hline \multicolumn{2}{|c|}{$\begin{array}{l}{ }^{3} \text { Faculty of Theology, Puritan } \\
\text { Reformed Theological } \\
\text { Seminary, Grand Rapids, } \\
\text { United States }\end{array}$} \\
\hline \multicolumn{2}{|c|}{$\begin{array}{l}\text { Correspondence to: } \\
\text { Brian DeVries }\end{array}$} \\
\hline \multicolumn{2}{|c|}{$\begin{array}{l}\text { Email: } \\
\text { bdevries99@gmail.com }\end{array}$} \\
\hline \multicolumn{2}{|c|}{$\begin{array}{l}\text { Postal address: } \\
\text { PO Box 04, Montana Park, } \\
\text { Pretoria 0159, South Africa }\end{array}$} \\
\hline \multicolumn{2}{|c|}{$\begin{array}{l}\text { Dates: } \\
\text { Received: } 20 \text { Mar. } 2015 \\
\text { Accepted: } 22 \text { June } 2015 \\
\text { Published: } 31 \text { July } 2015\end{array}$} \\
\hline \multicolumn{2}{|c|}{$\begin{array}{l}\text { How to cite this article: } \\
\text { DeVries, B.A., 2015, } \\
\text { 'Divine empowerment: } \\
\text { The Holy Spirit and church } \\
\text { revitalisation', In die Skriflig } \\
\text { 49(1), Art. \#1955, } 8 \text { pages. } \\
\text { http://dx.doi.org/10.4102/ } \\
\text { ids.v49i1.1955 }\end{array}$} \\
\hline \multicolumn{2}{|c|}{$\begin{array}{l}\text { Copyright: } \\
\text { C } 2015 \text {. The Authors. } \\
\text { Licensee: AOSIS } \\
\text { OpenJournals. This work is } \\
\text { licensed under the Creative } \\
\text { Commons Attribution } \\
\text { License. }\end{array}$} \\
\hline \multicolumn{2}{|l|}{ Read online: } \\
\hline 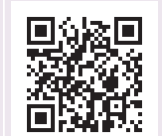 & $\begin{array}{l}\text { Scan this QR } \\
\text { code with your } \\
\text { smart phone or } \\
\text { mobile device } \\
\text { to read online. }\end{array}$ \\
\hline
\end{tabular}

How do principles of church revitalisation correlate with the divine work of the Holy Spirit? This article argues that the Spirit is the primary agent of church revitalisation, and church leaders should cooperate with the Spirit as he works for revitalisation. Thus the Spirit empowers church leaders who are used by him to revive, renew, and revitalise a church community. After briefly defining the Spirit's empowerment with biblical examples, this article examines the underlying principles of empowerment for church leaders, followed by briefly considering methodology for church revitalisation. The author concludes by suggesting several signs of biblical empowerment in a local church community.

Goddelike bemagtiging: Die Heilige Gees en kerkherstel. Watter plek beklee die goddelike werking van die Heilige Gees in die beginsels van kerkherstel? Hierdie artikel poneer dat die Heilige Gees die primêre agent is om nuwe lewe in die kerk te bring en kerkleiers behoort onder leiding van die Heilige Gees hulle hiervoor te beywer. Die Heilige Gees bemagtig dus die kerkleiers wat Hy gebruik om 'n kerklike gemeenskap te laat herleef, te vernuwe en hulle te besiel met lewenskragtigheid. Die Gees se bemagtiging word kortliks aan die hand van bybelse voorbeelde gedefineer, waarna die grondliggende beginsels vir die bemagtiging van die kerkleiers ondersoek word. Daarna word die metodologie om nuwe lewenskrag in die kerk te bring kortliks oorweeg. Die outeur sluit af deur verskeie tekens uit te lig wat op skriftuurlike bemagtiging van die Heilige Gees in die plaaslike kerkgemeenskap dui.

Church revitalisation has recently become an area of growing interest amongst various reformed and presbyterian ecclesial groups. Interest in this subject is seen in a growing body of literature ${ }^{1}$ as well as recent increase in attention amongst several conservative denominations. Church revitalisation ${ }^{2}$ is not a new concept, though perhaps a newer term that is closely related to revival ${ }^{3}$ and church renewal. ${ }^{4}$ Yet it represents a healthy and biblical approach to church renewal, and contemporary church leaders of established churches would do well to implement its principles in practice.

How do the principles and implementation of church revitalisation relate with the divine work of the Holy Spirit? As with many methodologies for church renewal, there is often in practice an apparent tension between divine sovereignty and human strategies for success. ${ }^{5}$ There has at times been a tendency in both church and mission to overlook the role of the Holy Spirit by emphasising human method and strategy (cf. DeVries 2007:18-94). The cardinal error of revivalism is committed by replacing the divine work of the Spirit with human means (cf. Finney 1868). ${ }^{6}$ Or more recently, church growth principles of strategies and techniques replace a humble dependence on God's sovereignty, often causing the Holy Spirit to become the forgotten factor in various pragmatic calculations. As William Abraham (2003) notes:

1.Several of the more helpful books include Dever (2004), Miller (1986), Mohler (2015), Reeder ili and Swavely (2004), Ross (2006) and Snyder (1989). Several recent popular books include Mclntosh (2009), McNeal (2009), Stetzer and Rainer (2010) and Swindoll (2010).

2.For the purpose of this article, church revitalisation will be defined as the process of giving new life or vigour to a church community. Revitalisation comes from the Latin vivere, meaning life or to live, with the prefix re- meaning again. Thus church revitalisation is giving life again to a church community, assuming that life or vigour was absent or declining. Church revitalisation is closely related to revival and reformation. J. Runia (1968) postulates: 'Reformation and Revival are the two sides of one reality. Just as there are two aspects in the church, the organizational visible and the spiritual-visible, so there are also two aspects in the renewal of the church, revival and reformation. There is no contradiction between the two, they constitute an inseparable unity' (p. 45).

3.For a biblical understanding of revival, see Murray (1998).

4.See, for example Abraham (2003), Miller (1999) and Oden (2006).

5.The classic study of this apparent tension as it relates specifically to evangelism is Packer (1961).

6.Charles Finney (1868) is the classic example: 'For a long time it was supposed by the Church that a revival was a miracle, an interposition of Divine power. It is only within a few years that ministers generally have supposed revivals were to be promoted by the use of means ... God has overthrown, generally, the theory that revivals are miracles' (pp. 12-13). 
In itself there is nothing at all wrong with a healthy commitment to develop policies and practices in evangelism that really do achieve intentionally adopted goals. What is at issue is the way this spirit begins to corrupt various aspects of evangelism ... and ... there is a real danger that the deeper theological and spiritual issues intimately related to evangelism will be set aside in the push to find a magic wand to increase church membership. (pp. 77-78)

Whilst past weaknesses must not be allow to dampen human desires for revitalised churches or hinder efforts to see this happen in one's own church community, one must also be careful to use only means and methods for revitalisation that the Holy Spirit will honour and bless. As with all ecclesial and missional activities in the kingdom, it is vitally important to have a clear understanding of the Holy Spirit's work, lest we find ourselves out of step with his activity.

The thesis of this article is that the Holy Spirit is the primary agent of church revitalisation, whilst ministers, church leaders, ministry workers, et cetera are only secondary agents of church revitalisation. Or put differently, Christians are called to be co-workers of the Holy Spirit as he is busy working for revitalisation individually in believers and collectively and communally in the whole church. The Holy Spirit empowers church leaders who are used by the Spirit to revive, renew, and revitalise an entire church community of believers.

In this article regarding the Spirit's role in church revitalisation, four areas will be considered, namely definition, principle, method, and evidence. Firstly, empowerment for church revitalisation and its implications for ministry in general are defined. Then the underlying principles of empowerment for church leaders are studied, followed by a brief considering of the methodology of empowerment for church revitalisation. Finally, the article is concluded by suggesting several signs of biblical empowerment in a local church community.

\section{Empowerment: Wait for power from on high}

Church revitalisation always begins as the work of the Holy Spirit in the church. This fact should come as no surprise to those who confess that the Holy Spirit is sovereign. The sovereignty of the divine Spirit, in both personal conversation and church renewal, has been confessed by Christians since the Early Church. Some church leaders seem - at least in practice - to make the divine work of the Spirit dependant on or conditional to human activity. Lloyd-Jones (1959) writes:

I would affirm that much of the modern approach to evangelism, with its techniques and methods, is unnecessary if we really believe in the doctrine of the Holy Spirit and His application of God's message. I suggest that our 'techniques' and our 'mechanics' actually divert the attention of people from 'the truth of the message' to some lower, particular, immediate and practical action which may have the opposite effect what is intended. (pp. 39-40)
But most protestant theologians have maintained, at least in theory, the sovereignty of the Holy Spirit in regeneration, in the believer's life of sanctification, and collectively in church renewal ${ }^{7}$ - even though in practice the Spirit's sovereignty can often be overlooked.

The history of the Early Church gives clear evidence in several biblical passages of the Spirit's sovereign power in the church. Perhaps the clearest passage is Acts 1:6-11, which gives an account of Jesus' parting instructions to the leaders of the New Testament Church. Parallel to the Great Commission passages, Jesus here instructs these church leaders to wait for divine empowerment for the task of witnessing of Christ. Acts 1:8 is essential to this passage and the whole book: 'But you will receive power when the Holy Spirit has come upon you, and you will be my witnesses in Jerusalem and in all Judea and Samaria, and to the end of the earth.' Thus, when the Holy Spirit would come, then they will receive power to be witnesses of Christ.

Jesus' parting instructions were not new for these church leaders. He had already given similar instructions. Earlier Jesus 'ordered them not to depart from Jerusalem, but to wait for the promise of the Father' (Ac 1:4). And shortly after his resurrection, Jesus said, 'You are witnesses of these things. And behold, I am sending the promise of my Father upon you. But stay in the city until you are clothed with power from on high' (Lk 24:48-49). It is evident that these concepts waiting for power from on high and being filled with the Holy Spirit in order to become witnesses of the things of Christ - were not strange to the disciples.

What is the promise of the Father and the power from on high of which Jesus spoke? The promise of the Father is the anticipated filling of the Holy Spirit that Jesus had spoken about in the Upper Room Discourse (Jn 13-17) and elsewhere (e.g. Lk 24:44-49; Jn 20:19-23). The Father's promise was fulfilled when the Holy Spirit was sent, by God the Father and the risen Christ, into the church for the first time at Pentecost (Ac 2:1ff.). The Holy Spirit, as promised, was poured out into the church at Pentecost, and he still continues to fill believers for gospel ministry.

Jesus spoke in Acts 1:8 and elsewhere of the power from on high. Again, it is the personal presence of the Holy Spirit who was predicted by Jesus Christ before his ascension. This power from on high should not be equated with a mystical energy as described by some religions (Sufi Islam, Eastern mysticism, postmodern spirituality, etc.). Nor is this power to be equated with the magical forces of either traditional religion (mana, muti, miracles, etc.) or modern sensationalists. The power of which Jesus spoke is none other than the Holy Spirit himself, who personally fills Christian believers with a measure of his presence and who empowers them for gospel ministry.

Without the presence and power of the Holy Spirit, all gospel ministry is to no avail. Thus the New Testament literature

7.For a historical study, see George Smeaton (1988). 
calls us to walk by the Spirit (Gl 5:16-26), to be filled with the Spirit (Eph 5:18), to be co-workers with the Spirit (2 Cor 6:1), et cetera. Therefore attempting church revitalisation without his empowerment contradicts the parting instructions of Jesus to the first leaders of the New Testament Church. Waiting upon the Spirit's presence and empowerment is a necessary prerequisite for church revitalisation.

The second passage, Acts 4:23-31, is equally important. The same truth is expressed, this time in living application within the gathered community of believers. This passage follows an account of the early persecution against the believers. Though challenged by the recent persecution, the believers gathered for corporate prayer, confessing God's sovereignty and praying for boldness to witness of Christ. God's immediate answer to their prayer is given in Acts 4:31: 'And when they had prayed, the place in which they were gathered together was shaken, and they were all filled with the Holy Spirit and continued to speak the word of God with boldness.'

The focus of this passage is not on the temporary and extraordinary shaking of the place, but on the two results, ${ }^{8}$ namely that all the believers (including but not limited to the apostles) were filled with the Holy Spirit, and that they continued to witness with boldness. The filling of the Holy Spirit is evidenced here as a fresh and deepened experience of the personal presence of the Holy Spirit in the life of a believer as a result of constantly walking in the Spirit (Gl 5:16-25) and living in a way that never grieves the Spirit (Eph 4:30; cf. Is 63:10; cf. also DeVries 2007:138-149; Köstenberger 1997:229-240). As a result of the Spirit's filling, the believers spontaneously spoke the Word with boldness. They were revived-we could say revitalised - by a fresh filling of the Holy Spirit, which spontaneously motivated them with boldness in gospel ministry. Thus one can conclude that whilst you are waiting for the Spirit's presence and empowerment, you should busy yourself - as did the believers in this passage with prayer that confesses God's sovereignty.

Additional passages in the book of Acts and other New Testament books also highlight the importance of the divine presence and empowerment of the Holy Spirit. Acts 11:1921, for example shows how the Holy Spirit as the primary agent used the cross-cultural witness of believers to work a revival in a new territory. It is clear from these passages and others that the Holy Spirit was sent into the church by the Father and Son in order to empower believers for gospel ministry, and that the presence and empowerment of the Spirit is necessary for church revitalisation.

\section{Principle: Competent ministers of Christ's Spirit}

The essential prerequisite for church revitalisation is the presence and empowerment of the Holy Spirit. As stated, church revitalisation always begins with the work of the

8.On this passage John Calvin (1998) writes: 'Whereas God did declare His power then by shaking the place it was a rare and extraordinary thing; and whereas it appeared by the effect, that the apostles did obtain that which they desired, this is a perpetual profit of prayer, which is also set before us for an example' (Acts 4:31) (p. 189)
Holy Spirit in the church. Yet confessing that the Holy Spirit is the primary agent of ministry in the church does not mean Christians do not have any work to do. Nor does it mean Christians should passively wait for some mystical experience of the Spirit's power, without doing the work we have already been instructed to do. Even whilst we - as secondary agents - wait for the power of the Spirit to work, we busy ourselves with speaking the Word and with prayer. Passionate prayer for the Spirit's divine work is the pattern of the Early Church in the book of Acts. Church history teaches the same lesson (Murray 1994:127-131).

What then should church leaders do to prepare for and promote church revitalisation? There is much to be done, whilst remaining grounded on and within the framework of biblical principles. Consider the following three principles related to the Holy Spirit and church revitalisation.

Firstly, church leaders cannot give new life or produce revival, but they can work and pray in faith. Acts 4:23-31, as just explained, is a clear example of this principle. The believers prayed for power to do what they had been commanded to do and were busy doing. Thus church leaders can pray for grace, power, and courage to do what will hopefully lead to church revitalisation. Confessing in prayer that they cannot produce revival or revitalise churches, places themselves and their ministries under the sovereignty of God; working in this personal weakness to preach the Word and witness of Christ causes them to trust in God's sovereignty and to hope for the results that only the Holy Spirit can produce. Thus their work in ministry, when based on the right principles, will cause them to confess their own weakness even whilst it also increases their trust and hope in God's Spirit (2 Cor 12:9-10).

Secondly, church leaders are not made competent by their own abilities or previous successes in ministry, but their competency is from God by his Spirit within them regardless of measurable results. This principle of spiritual competence is taught most clearly in 2 Corinthians 3:4-6:

Such is the confidence that we have through Christ toward God. Not that we are [competent] in ourselves to claim anything as coming from us, but our [competency] is from God, who has made us competent to be ministers of a new covenant, not of the letter but of the Spirit. For the letter kills, but the Spirit gives life.

The apostle Paul argues that God makes us competent for ministry, not by rhetoric or human wisdom (1 Cor 2:1-5), but in a living relationship with him by the Holy Spirit. When the Spirit continues to clear away the veil of unbelief and ignorance from our own eyes, and as we continue to gaze at the glory of Christ, only then, by the Spirit of life, we are transformed into the character of Christ (2 Cor 3:18). It is this transformation process that makes one a competent minister.

Competence in church revitalisation is not found, first of all, by promoting the sociological factors that are known to often make a church grow. Nor is it by certain communication skills 
or natural leadership ability. The secret of competence is not found in the application of church growth principles that may have produced results in the past. Spiritual competence for ministry is found only within a living relationship in the Spirit as we become increasingly Christ-like in our character and ministry.

It is in this living relationship with the triune God that the Holy Spirit fills us, produces fruit within us, and gives spiritual gifts that are used for the revitalisation of God's church. It is the filling of the Holy Spirit and his gifts that make us competent, not our own wisdom or abilities as empowered by these gifts. $^{9}$ Thus the source of competence should be highlighted and not just the abilities, methodologies, and strategies that the Spirit produces through us. This principle of competence in the Spirit gives Paul great confidence, hope, courage, freedom, and motivation for gospel ministry (2 Cor $3: 4,12,17 ; 4: 1)$.

Thirdly, we are dependent and the Holy Spirit is sovereign. The Spirit has chosen to use certain means and we are bounded by these means. The Spirit normally chooses to work together with us mediately (i.e. with the means), though he also works immediately (i.e. without means) and powerfully in the soul (cf. Packer 1990:295). ${ }^{10}$ Therefore whilst church leaders can participate with the Spirit in using means for spiritual conversion and church renewal, their work should be limited to using these means faithfully whilst leaving the outcome to the sovereign Spirit.

Yet because the Spirit's work is always effectual, our work should always be expectant. The Spirit always effectually accomplishes what he has intended to do, whether his purpose is only to vindicate Christ's righteousness or whether it is also to renew spiritual life in individuals and entire communities. Thus, as Paul writes, we are sincere and earnest and even humbly triumphant in our work: 'For we are not, as so many, peddling the word of God; but as of sincerity, but as from God, we speak in the sight of God in Christ'; (2 Cor 2:2:17; cf. also Edwards 2010). ${ }^{11}$

\footnotetext{
9.There is a subtle tendency, even while confessing dependency on the sovereign Spirit, to shift the focus from the Spirit's monergistic work of salvation and his essential co-witness that works through us, to a greater attention on the empowerment of us and the power this gives us. Following Charles Finney (1868) revivals in America increasingly were considered to be products of the evangelist who was empowered by the Holy Spirit; they were not considered to be products of the Holy Spirit who used the evangelist. Thus the focus of dependence shifted from dependency that trusted the Spirit for sovereign conviction and conversion, from dependency that trusted the Spirit for sovereign conviction and conversion, to dependency that trusted the Spirit for power to preach convincingly. Denying the Spirit's sovereign converting work in salvation, Finney instead overemphasised the Spirit's empowerment of the evangelist. As Bruce Stephens (1990) perceptively notes, Finney attempted: 'to reconcile a Pelagiaism $[\mathrm{sic}]$ that tended to reduc the role of the Spirit with a Pietism that urged reliance on the inducements of the Spirit, remaining ever expectant and watchful for even greater evidences of the power of the Spirit's workings' (p. 222).

10.Packer (1990) states: '[Regeneration] is effected by the Spirit, who acts both mediately, by the word, in the mind, giving understanding and conviction, and also immediately, with the word, in the hidden depths of the heart, implanting new life and power, effectively dethroning sin and making the sinner both able and willing to respond to the gospel invitation. The Spirit's work is thus both moral, by persuasion (which Arminiansand Pelagiansaffirm), andalso physical, by power (whichthey deny)' (p. 295).

11.Jonathan Edwards (2010) also knew the secret of this humble dependence and expectancy of victory: 'I think I have found that no discourses have been and expectancy of victory. "I think I have found that no discourses have been sovereignty, with regard to the salvation of sinners, and His just liberty, with regard to answering prayer, and succeeding the plans, of natural men, continuing such, have been insisted on' (pp. 849-850).
}

Therefore, in order to be competent church leaders who promote church revitalisation, they should seek consistently to operate grounded on these principles and within the framework of the Spirit's normal means for church renewal. It is in this way that one will increasingly walk by the Spirit and grow in spiritual ability so as to be used by the Holy Spirit in his work of revival, renewal and revitalisation.

\section{Methodology: The normal way of the Spirit's work}

It is important to study the means and methods that the Holy Spirit normally uses to produce church renewal. Since believers are dependent on his sovereign work and are competent only in their spiritual relation through him with Christ, it is vitally necessary for believers to pattern our methodologies according to the normal way of the Spirit's work. When we use methods that recognise the sovereignty of the Holy Spirit and that cooperate with his powerful work, then his power is operational through us and he will often sovereignly bless our feeble efforts. But if we use methods that are inconsistent with the Spirit's normal way of working or that do not confess his sovereignty we are likely wasting our efforts since it is less likely that he will bless these methods.

This seems to be the lesson of 1 Corinthians 2:1-5. Paul consciously chose not to use certain methods, neither because they were necessarily wrong, and nor because he did not desire to persuade sinners to be reconciled with God (cf. 2 Cor 5:11-21), but rather because he consciously bound himself to means which would demonstrate the Spirit and power, so that, ultimately, the faith of his audience would be grounded in God's power and not in Paul's ability. Church leaders likewise should pattern their methods after the normal work of the Spirit since they desire the same result, not of counterfeit change but of lasting spiritual church revitalisation.

What are the means and methods that the Holy Spirit normally uses to work church revitalisation? Many such methods can be gleaned from biblical examples and from church history. The following two methods, however, are most common. The Spirit always works by communicating the Word about Christ, and the Spirit usually starts to work by confronting sin. Our efforts and methods for church revitalisation therefore should be patterned after and consistent with these common works of the Holy Spirit.

Firstly, the Holy Spirit always works by communicating the Word about Christ. There is an inseparable relationship between Christ and the Spirit of Christ, and there is a perfect harmony between the objective truth as revealed in the Scriptures and the subjective witness of the Spirit who inspired the Scriptures. Indeed, the teaching of this relationship and harmony is one of the strengths of the reformed tradition. Though John Calvin's contributions are misunderstood by many, his explanation of the inseparable 
relationship of the Spirit and Word of God resonates with the biblical record and remains unsurpassed (cf. Packer 1987). ${ }^{12}$

As Calvin taught in many places, the communication of the gospel is made effective only when the Holy Spirit joins himself with the Word. ${ }^{13}$ Furthermore in relation to missional ministry and the Spirit's evangelistic conviction, J.H. Bavinck (1960) explains that the Holy Spirit:

convinces man of sin, even where previously no consciousness of sin was apparently present. The Holy Spirit uses the word of the preacher and touches the heart of the hearer, making it accessible to the word. (p. 229)

Thus the Word of God is the primary means of the Holy Spirit's work. There are many modes of how the Word can be communicated - preaching, teaching, counselling, evangelism, et cetera - but the method of the Spirit's work with the Word remains essential.

Secondly, the Holy Spirit usually starts to work by confronting $\sin$. On the night before his crucifixion, Jesus instructed his disciples that he would send the Holy Spirit to be with them (Jn 14:26ff.) and to empower them for witness (Jn 15:26-27). When the Holy Spirit comes, Jesus said, he would guide them into deeper understandings of the truth about Christ (Jn 16:13-15) - the Word joined by the Spirit as explained above - and he would 'convict the world concerning sin and righteousness and judgment' (Jn 16:8; cf. Calvin 2003b). ${ }^{14}$ This conviction of sin is usually the first work of the Holy Spirit in the life of every individual (cf. Sibbes 2001). ${ }^{15}$

The Spirit's work of conviction is for the purpose of causing people to recognise their sinfulness, to repent of their sin, and to run to Jesus Christ for the forgiveness and healing

12.Packer (1987) notes that: 'as Augustine was the theologian of grace and Luthe the theologian of justification, both par excellence, so Calvin was and remains the theologian of the Holy Spirit in the post-apostolic Christian church, with the Puritans and Edwards in close support. No one has ever surpassed these men; few have come near them' (p. 3).

See also Nuttall (1992:20-33) and Warfield (1900:xxxiii-xxxiv).

13.On Ezekiel 22, Calvin (2003c) writes: 'God indeed works efficiently by His own words, but we must hold that this efficacy is not contained in the words themselves,
but proceeds from the secret instinct of the Spirit ... This work of the Spirit ... is but proceeds from the secret instinct of the Spirit ... This work of the Spirit ... is
joined with the word of God. ... The external word is of no avail by itself, unless joined with the word of God. ... The external word is of no avail by itself, unless
animated by the power of the Spirit. ... The Holy Spirit penetrates our hearts, and thus enlightens our minds' (pp. 108-109).

On Isaiah 59:21, Calvin (2003a) writes: 'The 'Spirit' is joined with the Word, because, without the efficacy of the Spirit, the preaching of the gospel would because, without the efficacy of the Spirit, the preaching of the gospel would avail nothing, but would remain unfruitful. In like manner 'the word must not be the name of the Spirit, and swell with vain confidence in their own imaginations (p. 271; cf. also Calvin [1960:1.9.1]).

14.On the meaning of John 16:10, Calvin (2003b) writes: 'We must keep to the series of steps which Christ lays down. He now says that the world must be convicted of 'righteousness', for people will never hunger and thirst after righteousness, but on the contrary will contemptuously reject everything that is said about it unless they have felt convicted of ' $\sin$ '. We must understand that believers, in particular, cannot progress in the Gospel till they have first been humbled, and this cannot happen until they are aware of their sins. Certainly it is the particular task of the law to summon consciences to God's judgment-seat and to strike them with terror; but the Gospel cannot be preached properly without leading from 'sin' to 'right, but the 'ospel cannot be preached properly without leading from ' law that first clause of which Christ spoke' (p. 398).

15. Richard Sibbes (2001:274) writes: 'The Spirit that testifies to a man that his sins are pardoned him, doth it first by convincing a man of his sins.' John Owen (1965:189) writes: 'Let no man think to understand the gospel, who knoweth nothing of the law.' that he alone can give. ${ }^{16}$ Without the Spirit's work of conviction, there is no evangelical repentance and thus no true spiritual need for Jesus Christ and his salvation. Thus without this work of the Spirit there can be no personal regeneration, and corporately, no revitalisation in the church. This has also historically been the usual pattern of the Spirit's work in times of revival. Murray (1994:163ff.) states: 'All awakenings begin with the return of a profound conviction of sin.'

What does this conviction of sin look like in practical cases of church revitalisation? In individuals, this conviction is usually seen in a growing awareness and aversion for internal sins such as pride, jealousy, lust, discontent, and the favourite sins to which a person is most susceptible. In relationships amongst Christians, this conviction is seen in renewed efforts to correct longstanding sins such as bitterness, division, and a lack of forgiveness toward each other. In church communities, this conviction is seen in the decrease of complacency, self-reliance, racial prejudice, and an attitude of superiority to those outside the community. These deeply rooted sins are often confessed and forsaken when the Spirit works, thus producing the desired revitalisation amongst believers in the church community.

Thus there is very often a consistent pattern in the Spirit's work. Church leaders and even members are empowered by the Holy Spirit to communicate the Word of Christ with sincerely and boldness (cf. Ac 4:31) and the Spirit uses this sincere witness of the Word to convict sinners - both believers and non-believers of the truth about Christ, often leading to cases of personal regeneration and sometimes church revitalisation. The pattern of the Spirit's work is often not sensational - miraculous signs and wonders are not an indisputable sign that the Holy Spirit is present (Edwards 1994:54-110). The pattern is very often relational, since it involves the personal witness of the Word between people and since it leads to confession of sins that had formally promoted bitterness and division. The Spirit's work is always exclusively Christ-focused (Jn 16:13-15) and it is always God-glorifying.

Since the Holy Spirit normally works in these ways, believers are wise to pattern their own methods after his divine movement. Many people have sought for a golden key in ministry, a perfected method that will produce the desired results quickly or almost effortlessly (cf. Wakely 2004:12-22). But this is a dangerous temptation based on a flawed understanding of the Spirit and his work. Often the result of golden key methodologies is that ministries become built on some other measure of success - very often on attendance numbers or other highly visible factors and not on biblical evidence of spiritual revival and lasting church revitalisation. Church leaders must rather make

16.Carson (1980) postulates: 'As a prosecutor the Holy Spirit aims to convict the defendant, the person who belongs to the world; but 'convict' in this context does not mean 'secure a conviction before a judge', but rather 'drive home personal conviction in an individual's heart and mind'. The aim of the Spirit's work is not to produce a guilty verdict - that already stands ([John] 3:18,36) - but to bring the defendant to see the perilous condition in which he stands. That may prompt him to enter a plea for mercy; for only mercy will save him' (p. 139).

See also Carson (1979:547-566). 
every effort to pattern their ministry methods after the movement of the Spirit and to always seek consistency with his way of working.

Thus church leaders are dependent on the Holy Spirit for his divine empowerment and sovereign blessing. They are limited and cannot by themselves produce the desired result of church revitalisation. They must rather keep in step with the Spirit by cooperating with his normal means of working and by doing what he is most likely to bless. With this methodology believers are mostly likely to see the desired results of spiritual revitalisation.

\section{Evidence: Signs of the Holy Spirit's presence}

The Holy Spirit is the divine agent who produces church revitalisation. He normally uses us as secondary human agents to communicate the Word of Christ through various modes of ministry. As we confess our dependence on the Holy Spirit and as we are faithful in ministry, he may sovereignly choose to work repentance and revitalisation in the church. Thus we are called to be co-workers of the Holy Spirit, as he is busy working for revitalisation individually in believers and collectively and communally in the whole church.

The need for divine empowerment has already been considered, as well as the personal presence and power of the Holy Spirit in our ministries. The need to be grounded in, and to operate within biblical principles concerning the Spirit's work have been studied. The importance of patterning our ministry methods after the normal way the Spirit works was also indicated. The vital question in conclusion, therefore is how such a ministry will look in practice. What is the biblical evidence of spiritual church revitalisation and what are the sure signs of the Holy Spirit's presence in our ministry?

There is much talk today by many church leaders about the Spirit's presence, power, guidance, prophecy, blessing, et cetera. Consider, for example the sensational ministries of signs and wonders, contemporary healing ministries, and the abundance of deliverance ministries that all claim to be influenced by the Spirit of God. Many claim to be working in the power of the Holy Spirit, even whilst they are doing things that are clearly in contradiction with the Bible, the Word given to us by the Holy Spirit himself. ${ }^{17}$

These various waves of charismatic renewal, however, should not cause church leaders to be afraid of building their ministries on biblical truths about the Holy Spirit.

17. Discernment here is of crucial importance. Several simple diagnostic questions can quickly suggest the presence of an evil spirit who is trying to falsely impersonate the Holy Spirit, for example: Are the objective teachings of these ministries - in both word and action, both for short-term and over time - consistent with the both word and action, both for short-term and over time - consistent with the whole Bible?; Do these ministries focus all attention exclusively on Jesus Christ as proclaimed to us in the Word of God?; Do these ministers lead to a conviction of the presence of the Spirit of Holiness?
They should rather return to the Bible, with guidance by confessional documents and time-tested Pneumatology (cf. Goodwin 1996; Kuyper 1900; Owen 2004), to reassert a biblical doctrine of the Holy Spirit that seeks with great discernment to reject contemporary excess and to return again to the same sincere dependency on the Holy Spirit in ministry that was experienced for the first time by Early Church leaders (Ac 6:3; 11:24; 13:52; 1 Cor 2:1-5; 2 Cor 3; etc.).

How then should one measures success in church revitalisation, assuming the sovereign role of the Holy Spirit? It is necessary in conclusion to reflect briefly on biblical evidences of the Spirit's presence in ministries. These evidences are touchstones for ministries - they serve as tests and criterion for determining the genuineness of church revitalisation. The following list is not exhaustive but serves only as a framework for personal reflection and discernment.

Firstly, evidence of theSpirit's presencein church revitalisation is not necessarily measurable. We are often tempted to look at measurable factors such as average weekly attendance, the number of people accepting Christ, crowd size at various events, growth of ministry commitments, amount of money collected monthly or at events, published results in popular or academic media, the praise of man, and more other factors. But none of these are infallible measures of success in church revitalisation. They may indicate something good or bad about the methods, but there is no direct correlation between any of these and the sovereign work of the Holy Spirit.

In 1944 Edwards, an American theologian used by God during the Great Awakenings, sternly cautions against using untrustworthy factors as evidence of spiritual success:

It is strange how hardly men are brought to be contented with the rules and directions Christ has given them, but they must needs go by other rules of their own inventing that seem to them wiser and better. (p. 114) $)^{18}$

Jesus says that the Spirit is like the wind, which is not detected physically and cannot be controlled (Jn 3:8). It should be no surprise, therefore, that tools for sociocultural analysis can only describe what the Spirit has done through us and cannot prescribe factors for any future success. Such thinking is the subtle flaw of American church growth principles that are more characterised by a socalled sanctified pragmatism than by the precise spiritual discernment of Jonathan Edwards.

Secondly, the evidence of the Spirit's presence should be seen in the character and ministry of the minister and of

18.Edwards (1994) carefully identifies twelve uncertain evidences of revival, viz. very great and high affections (p. 54), great effects on the body (p. 59), fluent, fervent and abundant talk about religious things (p. 62), affections motivated by cause outside of oneself ( $p .65$ ), texts of Scripture 'remarkably brought to the mind' ( $p$. 70 ), an appearance of love in the affections (p. 73), many affections at once of different kinds (p.75), comforts and joys which seemingly follow convictions (p. different kinds ( $p .75$ ), comforts and joys which seemingly follow convictions ( $p$. 79 ), devotion and zeal in religious duties (p. 91), encouraging others to praise and approval of one's experiences by the truly godly (p. 110). 
the entire church leadership. Since church leaders are only cooperating in church revitalisation with the Spirit's divine work of renewal, it is of great importance that they are filled by the Holy Spirit. When the Spirit is at work in the church, usually the leaders of that church will be the first to display humble dependence on the Spirit's divine work and demonstrate signs of his presence in their lives such as authentic holiness, ${ }^{19}$ passion for ministry (cf. Drummond 1992), ${ }^{20}$ and growth in spiritual gifts. The presence of the Holy Spirit is also experienced amongst the church leadership as unity in the truth, discernment and courage to deal with error, motivation to witness of Christ, and love for lost souls.

Thirdly, evidence of the Spirit's presence for church revitalisation is seen individually in the character of church members and collectively in the whole body of the church. When the Spirit is present amongst the members, there will be an increased awareness of a hatred for sin and the underlying sinfulness. There will also be growth in grace

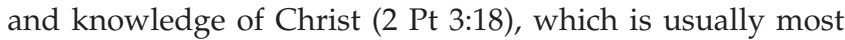
evident through increased motivation for personal holiness and for participation in ministry. When the Spirit is present within the whole church, believers will return from times of spiritual backsliding and others will experience renewed spiritual life and spiritual closeness with Christ. As Harry Reeder (quoted in Landry 2009) states:

Transformed lives through the gospel of grace resulting in a testimony of the pre-eminence of Christ. The Holy Spirit will be at work and no one will be speaking about Him because his work is that everyone will be speaking of and proclaiming Christ.

How then should church leaders work for the revitalisation of their churches? Since church revitalisation is ultimately the work of the Holy Spirit, they should first confess his sovereignty and learn to depend more consistently on him in their ministry. A life of personal and corporate prayer is often the best means to constantly train our minds to confess the Spirit's sovereignty in practical ways. They should analyse their ministry methods to ensure they are based on biblical principles and are consistent with a biblical doctrine of the Holy Spirit. As they wait for the Spirit's special presence and power, they should be busy using the means he has usually blessed in the past, viz. the clear and simple communication of the Word that usually leads to evangelical repentance and faith in Christ. As they confess their dependence on the Holy Spirit and as they are faithful in ministry, he may sovereignly choose to work repentance and revitalisation in the church.

19.The holiness of a minister gives great power and authenticity to the message that he brings. This authentic holiness is, of course, only possible through the continual gracing and sanctification of the Spirit, and by a conscious effort to continually mature in biblical spirituality.

20.Drummond (1992) declares:A shallow emotional, approach to spirituality is not desired. God desires His witnesses to be burdened, concerned, enthusiastic, and zealous to spread the good news to the millions who desperately need to hear the message. The Holy Spirit will instill this attitude in believers as they seek strength, misdom, and compassion (p. 331).

\section{Acknowledgements Competing interests}

The author declares that he has no financial or personal relationship(s) that may have inappropriately influenced him in writing this article.

\section{References}

Abraham, W.J., 2003, The logic of renewal, Eerdmans, Grand Rapids.

Bavinck, J.H., 1960, An introduction to the science of missions, transl. D.H. Freeman, Presbyterian \& Reformed Publisher, Phillipsburg.

Calvin, J., 1960, Institutes of the Christian religion, ed. John McNeill, transl. F.L. Battles, The Westminster Press, Philadelphia.

Calvin, J., 1998, Calvin's commentaries: Acts, electronic ed., Logos Library System, Albany.

Calvin, J., 2003a, Commentary on the book of the prophet Isaiah, transl. W. Pringle, Baker Books, Grand Rapids.

Calvin, J., 2003b, Commentary on the Gospel according to John, Baker Books, Grand Rapids.

Calvin, J., 2003c, Commentary on the prophet Ezekiel, vol. 1, transl. W. Pringle, Baker Books, Grand Rapids.

Carson, D.A., 1979, 'The function of the paraclete in John 16:7-11', Journal of Biblical Literature 98, 547-566.

Carson, D.A., 1980, The farewell discourse and final prayer of Jesus: An exposition of John 14-17, Baker Book House, Grand Rapids.

Dever, M., 2004, Nine marks of a healthy church, Crossway Books, Wheaton.

DeVries, B.A., 2007, 'Witnessing with the Holy Spirit: Pneumatology and missiology in evangelistic theory', PhD dissertation, Faculty of Theology, Southern Baptist Theological Seminary, Louisville.

Drummond, L.A., 1992, The word of the cross: A contemporary theology of evangelism Broadman, Nashville.

Edwards, J., 1994, The religious affections, Banner of Truth, Carlisle.

Edwards, J., 2010, 'A faithful narrative of the surprising work of God', Works 1, 849-850.

Finney, C.G., 1868, Lectures on revivals of religion, Revell, New York.

Goodwin, T., 1996, The works of Thomas Goodwin, vol. 6, Tanski Publications, Eureka.

Köstenberger, A.J., 1997, 'What does it mean to be filled with the Spirit? A biblical investigation', Journal of the Evangelical Theological Society 20(4), 229-240.

Kuyper, A., 1900, The work of the Holy Spirit, transl. Henri DeVries, Funk \& Wagnalls, New York.

Landry, E., 2009, 'Interview with Harry Rheeder', The White Horse Inn blog, viewed 15 November 2014, from http://www.whitehorseinn.org/blog/2009/10/09/fivefor-friday-4/

Lloyd-Jones, D.M., 1959, Conversions: Psychological and spiritual, InterVarsity, Chicago.

McIntosh, G.L, 2009, Taking your church to the next level: What got you here won't get you there, Baker Books, Grand Rapids.

McNeal, R., 2009, Missional renaissance: Changing the scorecard for the church, Jossey-Bass, San Francisco.

Miller, C.J., 1986, Outgrowing the ingrown church, Zondervan, Grand Rapids.

Miller, D., 1999, Reinventing American Protestantism: Christianity in the new millennium, University of California Press, Oakland.

Mohler, R.A., 2015, A guide to church revitalization, SBTS Press, Louisville.

Murray, I.H., 1994, Revival \& revivalism: The making and marring of American Evangelicalism 1750-1858, Banner of Truth, Carlisle.

Murray, I.H., 1998, Pentecost - Today? The biblical basis for understanding revival, Banner of Truth, Carlisle.

Nuttall, G.F., 1992, The Holy Spirit in Puritan faith and experience, University of Chicago Press, Chicago.

Oden, T.C., 2006, Turning around the mainline: How renewal movements are changing the church, Baker Books, Grand Rapids.

Owen, J., 1965, 'The doctrine of justification by faith', in J. Owen (ed.), Works, vol. 5 , pp. 1-400, Banner of Truth, London.

Owen, J., 2004, The Holy Spirit: His gifts and power, Christian Focus, Ross-Shire.

Packer, J.I., 1961, Evangelism and the sovereignty of God, InterVarsity, Downers Grove.

Packer, J.I., 1987, 'The Holy Spirit and his work', Crux 23, 2-17.

Packer, J.I., 1990, A quest for godliness: The puritan vision of the Christian life, Crossway Books, Wheaton.

Reeder III, H.L. \& Swavely, D., 2004, From embers to a flame: How God can revitalize your church, P \& R Publishing, Phillipsburg.

Ross, M., 2006, Preaching for revitalization: How to revitalize your church through your pulpit, Mentor, Ross-Shire. 
Runia, J., 1968, Reformation today, Banner of Truth, Carlisle.

Sibbes, R., 2001, The works of Richard Sibbes, vol. 7, Banner of Truth, Carlisle.

Smeaton, G., 1988, The doctrine of the Holy Spirit, The Banner of Truth, Carlisle.

Snyder, H., 1989, Signs of the Spirit: How God reshapes the church, Zondervan, Grand Rapids.

Stephens, B.M., 1990, 'Changing conceptions of the Holy Spirit in American protestant theology from Jonathan Edwards to Charles Finney', Saint Luke's Journal of Theology 33, 222.
Stetzer, E. \& Rainer, T.S., 2010, Transformational church: Creating a new scorecard for congregations, B\&H Books, Nashville.

Swindoll, C.R., 2010, The church awakening: An urgent call for renewal, FaithWords, New York.

Wakely, M., 2004, 'The search for the golden key', Evangelical Missions Quarterly $40(1), 12-22$.

Warfield, B. B., 1900, 'Introductory note', in A. Kuyper (ed.), The work of the Holy Spirit, pp. xxxiii-xxxiv, Funk \& Wagnalls, New York. 